\title{
Otto Loewi (1873-1961): Dreamer and Nobel laureate
}

Alli N $\underline{\text { McCoy }}{ }^{1}, \mathrm{MD}, \mathrm{PhD}$, Siang Yong $\underline{\operatorname{Tan}^{2}}, \mathrm{MD}, \mathrm{JD}$

I ronically, Otto Loewi is better known for the way in which he came upon the idea that won him the Nobel Prize than for the discovery itself. Loewi's prize-winning experiment came to him in a dream. According to Loewi, "The night before Easter Sunday of [1920] I awoke, turned on the light and jotted down a few notes on a tiny slip of thin paper. Then I fell asleep again. It occurred to me at 6.00 o'clock in the morning that during the night I had written down something important, but I was unable to decipher the scrawl. The next night, at 3.00 o'clock, the idea returned. It was the design of an experiment to determine whether or not the hypothesis of chemical transmission that I had uttered 17 years ago was correct. I got up immediately, went to the laboratory, and performed a simple experiment on a frog heart according to the nocturnal design."

In that famous experiment, Loewi placed two beating frog hearts, each in its own perfusion chamber - one preparation had the vagus nerve intact, while the other was denervated. Next, he stimulated the vagus nerve supplying the first heart, causing it to beat more slowly - a phenomenon that was already well known at the time. When Loewi applied the perfusate of the first heart to the second heart, it too slowed down, as if its vagus nerve had been stimulated as well. In a related experiment,

Loewi showed that perfusate from a heart whose accelerator nerve was stimulated would cause a second heart to beat more quickly. He named the inhibitory factor 'vagusstoff', which is known today as acetylcholine. Loewi's dream thus led to the discovery that the primary language of nerve cell communication is chemical, not electrical, and won its dreamer the Nobel Prize in Medicine.

\section{FROM DOCTOR TO PHARMACOLOGIST}

Loewi was a dreamer from the first. Born in Frankfurt, Germany, into a Jewish family of wealthy wine merchants, he received a classical education in Latin and Greek, and dreamed of attending graduate school to major in art history. However, despite Loewi's preoccupation with the arts, his father was able to persuade him to become a physician. For his medical education, he matriculated at Strasbourg, where he reportedly skipped many classes to attend lectures in the humanities. He barely passed the end-of-year examination, requiring a year of remediation before he was able to complete his medical degree in 1896.

Loewi's first job as an assistant in the city hospital at Frankfurt proved frustrating, as he could not provide effective treatment for patients with tuberculosis and pneumonia. Disheartened, he decided to leave clinical medicine for a basic science research position in the laboratory of prominent German pharmacologist, Hans Meyer, at the University of Marburg an der Lahn. While Loewi would eventually win international acclaim for his contribution to neuroscience, his career as a scientist began in the unrelated field of metabolism. For

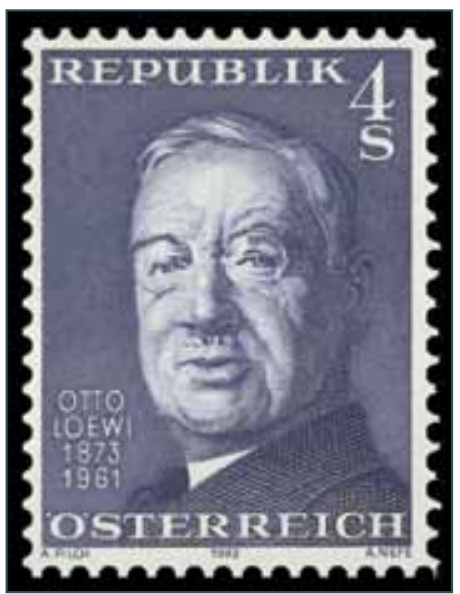

the next six years after joining Meyer's lab, he researched glucose metabolism and nutrition, and showed, among other things, that animals were able to rebuild proteins from amino acids. His early research dealt with the action of drugs in biological systems, finding that small doses of cocaine potentiated the response to either direct sympathetic nerve stimulation or exogenous epinephrine. He also studied the mechanism of action of diuretics and the phenomenon of epinephrine hyperglycaemia. In 1908, Loewi became a professor of pharmacology at the University of Graz in Austria, gaining a reputation as a lively lecturer. There, he also briefly served as dean of the medical faculty in 1912-13.

NEUROPHARMACOLOGISTS In 1902, Loewi visited the research laboratory of famed English physiologist, Ernest Starling, in London. There, Loewi met Henry Dale, who would become a lifelong friend and colleague. Revisiting England the following year, Loewi met Thomas Renton Elliott, who was then a medical student studying epinephrine and nerve cell communication under John Langley at the University of Cambridge. It has been suggested that the idea of chemical neurotransmission came up during discussions between Elliott and Loewi. Elliott had found that adrenaline mimicked the effects of sympathetic nerve stimulation, and surmised that adrenaline might be the chemical stimulant liberated whenever the nerve impulse arrives at the periphery. An earlier report by Walter Ernest Dixon, another English pharmacologist, had hinted at the possibility of the release of an inhibitory substance

${ }^{1}$ Research carried out during Transitional Medical Residency, University of Hawaii, ${ }^{2}$ Emeritus Professor of Medicine, University of Hawaii, Honolulu, USA 
upon stimulation of the vagus nerve. However, published in an obscure journal, these results escaped scientific notice.

A fellowship student in Langley's laboratory before Elliott, Dale, like Loewi, had also abandoned clinical medicine for bench research. Dale isolated and identified important neurochemicals, including histamine and acetylcholine, and distinguished acetylcholine's activity as being muscarinic or nicotinic, which foreshadowed the discovery of receptor classes and subtypes. Dale coined the terms 'parasympathomimetic' and 'sympathomimetic', and observed similarities between acetylcholine action and parasympathetic nerve stimulation. Noting the relatively transient effect of acetylcholine, he correctly predicted the presence of an esterase in the body that rapidly metabolised acetylcholine. Dale's findings complemented Loewi's, and together they shared the 1936 Nobel Prize in Physiology or Medicine for discoveries related to chemical neurotransmission. In their acceptance speech, they appropriately acknowledged the contributions of Elliott and Dixon.

It was this immersion in the new milieu of neuropharmacology that prepared Loewi to act on the experiment that came to him in a dream. Chance indeed favoured the prepared mind, with Luck playing her mystical part. Had Loewi carried out his experiment during a different time of day, year, or on a different species of frog, the results might have been inconclusive. Under slightly different circumstances, acetylcholine would have been rapidly metabolised by cholinesterase before it could reach the second heart. Time of day and season mattered. It turned out that in the dead of the night on a whim, precipitated by a dream, Loewi had carried out the perfect experiment during a perfect time in the frog's diurnal cycle.

FROM AUSTRIA TO AMERICA World War II cut short Loewi's distinguished career in the sciences. In 1938, the Germans invaded Austria, and Loewi and his two sons were arrested by the Gestapo at gunpoint. Imprisoned and brutalised, news of his plight reached the International Physics Congress in Zurich, where an international uproar by scientists and friends prompted his release. Permitted to leave Austria upon surrendering his money from the Nobel Prize, Loewi arrived in England in September 1938. There, he lived with Dale for several weeks before being offered a position at the Nuffield Institute in Oxford. The following year, Loewi emigrated to the United States, accepting a position as a research professor of pharmacology at New York University. He became a naturalised American in 1946.

Although Loewi's groundbreaking discoveries were made in Europe, he continued to stay academically active in his newly adopted country. He was also able to relive his childhood delights by surrounding himself with the music and literature of the New World, and in 1954, he was elected to the prestigious Royal Society of London. In the United States, Loewi spent each summer as a cherished and active member of the famous Woods Hole scientific community at the Marine Biological Laboratories in Massachusetts. However, in 1958, Loewi fractured his pelvis during a bad fall, and friends thereafter had to physically assist him in making his summer sojourns. In his final years, Loewi continued to find inspiration from the arts. As a New York Times obituary noted, "The years of Dr Loewi have so overflowed with devotions to art, literature, music, mountain climbing, human fellowship, and the science of biology [...]" Mentally alert to the end, Loewi fell silent after a lively discussion with a friend, and died on Christmas Day in 1961 at 89 years old. His ashes were buried in a churchyard outside his Woods Hole laboratory.

\section{BIBLIOGRAPHY}

- Friedman AH. Circumstances influencing Otto Loewi's discovery of chemical transmission in the nervous system. Pflugers Arch 1971; 325:85-6.

- Holmstedt B, Liljestrand G, eds. Readings in pharmacology. New York: McMillan Company, 1963.

- Karczmar AG. The Otto Loewi Lecture. Loewi's discovery and the XXI century. Prog Brain Res 1996; 109:1-27, xvii.

- Kyle RA and Shampo MA. Otto Loewi (1873-1961). JAMA 1979; 241:463.

- Loewi O. The chemical transmission of nerve action. In: Nobel Foundation. Nobel Lectures: Physiology or Medicine, 1922-1941. Amsterdam: Elsevier, 1965, 416-29.

- Loewi O. An autobiographic sketch. Perspect Biol Med 1960; 4:3-25.

- Loewi O. On the background of the discovery of neurochemical transmission. J Mt Sinai Hosp N Y 1957; 24:1014-6.

- Loewi O. On the antagonism between pressor and depressor agents in the frog's heart. J Pharmacol Exp Ther 1949; 96:295-304.

- Valenstein ES. The discovery of chemical neurotransmitters. Brain Cogn 2002; 49:73-95.

- Zigmond MJ. Otto Loewi and the demonstration of chemical neurotransmission. Brain Res Bull 1999; 50:347-8.

- Zimmer HG. Otto Loewi and the chemical transmission of vagus stimulation in the heart. Clin Cardiol 2006; 29:135-6. 